\title{
In the Ruins of
}

Neoliberalism

WELLEK LIBRARY LECTURES 
The Wellek Library Lectures in Critical Theory are given annually at the University of California, Irvine, under the auspices of UCI Critical Theory. The following lectures were given in May 2018.

\author{
UCI Critical Theory \\ James A. Steintrager, Director
}

For a complete list of titles, see page 249 . 


\title{
In the Ruins of
}

\section{Neoliberalism}

\author{
THE RISE OF \\ ANTIDEMOCRATIC \\ POLITICS \\ IN THE WEST
}

WENDY BROWN

Columbia University Press

New York 


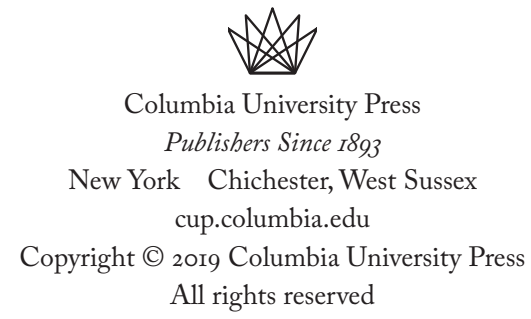

Library of Congress Cataloging-in-Publication Data

Names: Brown, Wendy, I955- author.

Title: In the ruins of neoliberalism : the rise of antidemocratic politics in the West / Wendy Brown.

Description: New York : Columbia University Press, 2019. |

Series: The Wellek Library lectures | Includes

bibliographical references and index.

Identifiers: LCCN 20I8060444 | ISBN 978023II93849

(cloth : alk. paper) | ISBN 9780231193856 (pbk. : alk. paper) |

ISBN 9780231550536 (ebook)

Subjects: LCSH: Democracy—Social aspects-Western countries. |

Neoliberalism-Political aspects-Western countries. | Right-wing extremists-Western countries. | Populism-Western countries. |

Right and left (Political science)-Western countries. | Political culture-Western countries.

Classification: LCC JC423.B83 2019 | DDC 306.209182/I-dc23

$\mathrm{LC}$ record available at https://1ccn.loc.gov/2018060444

Columbia University Press books are printed on permanent and durable acid-free paper.

Printed in the United States of America

Cover image: (C) Reuters/Lucas Jackson 